\title{
YOU ARE WHAT YOU ATE: CONSUMING THE PAST TO BENEFIT THE PRESENT
}

\author{
Iona M'cleery, Vicky Shearman And Jo Buckberry \\ University of Leeds, WaKefield Council and University of Bradford \\ UNITED KINGDOM
}

Date of receipt: $15^{\text {th }}$ of August, 2016

Final date of acceptance: $7^{\text {th }}$ of November, 2016

\section{Abstract}

You Are What You Ate was a British public engagement project funded by the Wellcome Trust between 2010 and 2014. It was a collaboration between the University of Leeds, the University of Bradford and Wakefield Council, especially its museums, schools and libraries, which aimed to use medieval food as a way to encourage reflection about modern food and lifestyle. The innovative project ran three exhibitions in Wakefield and Pontefract, a mobile exhibition, numerous schools and youth workshops, and a series of market stalls and osteology workshops for adults and children in the Yorkshire region. This article provides an overview of the project's aims, activities, outcomes, including an analysis of how to evaluate them, and its legacy.

\section{KeYWORDS}

Food, Nutrition, Health, Archaeology, Wakefield, Public Engagement.

\section{Capitalia Verba}

Cibus, Nutrimen, Salus, Archeologia, Wakefield, Compromissum publicum. 


\section{Introduction}

"The class was interested in the fact that the idea of healthy eating was hundreds of years old". ${ }^{1}$

The You Are What You Ate project ran for four years between 2010 and 2014. Funded by a Wellcome Trust Engaging Science grant, ${ }^{2}$ the project was a collaboration between the University of Leeds, the University of Bradford and Wakefield Council, two higher education institutions and the authority responsible for the district of Wakefield, all based in West Yorkshire in northern England. ${ }^{3}$ The project's sub-title was 'Food Lessons from the Past'. Its main aim was to engage the modern community in research on food and nutrition in order to encourage people to reflect on their own eating habits. The project team chose the period 1300-1700 to represent 'the past', but the innovative project was highly flexible, extending far beyond this period to reflect museum collections and community interests. ${ }^{4}$

The project team was made up of historians, museum officers, re-enactors, archaeologists and food scientists who worked together to plan and deliver three six-month exhibitions, a mobile exhibition, twenty osteology workshops for adults (handling real human bones) and children (handling plastic bones that had been given artificial pathologies), workshops at over fifty primary schools (child ages 7-11), numerous family and youth club sessions, twenty market stalls, two public conferences and evening talks. The project altogether involved nearly 150,000 engagements with a diverse cross-section of English society. Originally due to end in summer 2013, the Wellcome Trust granted a further year's funding (total funding: $£ 191,784$ ). This essay will outline the project's aims, project management, our methods of evaluation and the project's reach and significance. Research on food proved to be a particularly effective way of presenting multiple pasts for present audiences. ${ }^{5}$

1. Teacher's feedback on a questionnaire after one of our school workshops on November 16, 2011.

2. Grant no. 092293.

3. For the Wellcome Trust, see: Wellcome Trust. “Home”. Wellcome Trust. 10 June $2016<$ https://wellcome. ac.uk/>.

4. See the still live project website for full details: University of Leeds; University of Bradford; Wakefield Council. "home". You are what you ate. 10 June 2016 <http://www.leeds.ac.uk/youarewhatyouate/>.

5. The title of this essay is informed by Jerome de Groot (in: De Groot, Jerome. Consuming History: Historians and Heritage in Contemporary Popular Culture. Abingdon: Routledge, 2009), and John Arnold, Kate Davies and Simon Ditchfield (in: Arnold, Johne; Davies, Kate; Ditchfield, Simon, eds. History $\theta$ Heritage: Consuming the Past in Contemporary Culture. Shaftesbury: Donhead Publishing, 1998). 


\section{Aims and Geographical Context}

"The proposal is a well-meaning attempt to draw the public (children and adults) into areas of research that are of interest to food historians and bioarchaeologists". ${ }^{6}$

The You Are What You Ate project was devised in response to a Wellcome Trust Society Award funding call on the theme of eating in 2009. Society Awards were large grants that aim to:

stimulate interest, excitement and debate about biomedical science and/or the history of medicine; support formal and informal learning; reach audiences of all ages and from all walks of life and inform, inspire and involve them; encourage high-quality interdisciplinary practice and collaborations; [and] investigate and test new methods of engagement, participation and education. ${ }^{7}$

The project emerged as an idea during the International Medieval Congress (IMC) in Leeds in July 2009, an annual event attended by all three of the present authors (who had not previously met). ${ }^{8}$ It was then planned in a series of workshops in Leeds and Wakefield during autumn 2009 and spring 2010 at which time several other key people became involved: Gary Williamson (food scientist, University of Leeds), Janet Cade (nutritional epidemiologist, University of Leeds), Maya Harrison (Senior Cultural Officer, Wakefield Council), Caroline Yeldham (independent historical cook) and Alan Ogden (Biological Anthropologist and former clinical lecturer in dentistry, University of Bradford). The expansion of the team allowed us to bring together four underpinning research strands for an ambitious proposal: history of food and medicine; food science and nutrition; bioarchaeology; and museums, heritage and re-enactment.

The aims of the project as outlined in the original application were as follows:

- To enable extensive public engagement with research in biomedical science, medical history, bioarchaeology (osteoarchaeology and palaeopathology).

- To bring together bioarchaeologists, cultural officers, historians and nutritional experts and deliver innovative workshops and exhibitions, creating opportunities for research impact and improving public participation in cultural activities.

- To bring dietary issues to a wide audience in Yorkshire, working with schools, going out onto the street at festivals and putting on exhibitions.

- To encourage public debate and personal reflection about eating habits through exploration of the dietary choices of the past.

- To disseminate new methods of knowledge transfer and share good practice in order to inspire further public engagement initiatives.

6. Anonymous reviewer of the Welcome Trust, attachment in e-mail, March 17, 2010.

7. Wellcome Trust. "Wellcome Trust Sciety Awards". Wellcome Trust. 19 November 2014 <http://www. wellcome.ac.uk/Funding/Public-engagement/Funding-schemes/People-Awards-and-Society-Awards/ index.htm>.

8. The link with the IMC was maintained with sessions, round tables and a market stall in 2010-2013. 
The project team learned that it had been successful in its grant application in May 2010. The first event (a market stall) took place at a medieval fair at Pontefract Castle on 24 July 2010. The last event (an evening talk by well-known food historian Ivan Day) took place at Castleford Forum Museum on 23 September 2014. ${ }^{9}$ This length of time is unusual, helping to explain our success.

The project team achieved its aims through a wide range of activities for adults and children, mainly in the Wakefield region. The development of a partnership between Wakefield Council and the two universities, well-known for their work in medieval studies (Leeds) and bioarchaeology (Bradford), was closely related to Wakefield's well-documented medieval past. The region has two medieval castles, Sandal and Pontefract, and twelve medieval churches. The Battle of Wakefield (1460) was one of the most decisive conflicts of the Wars of the Roses. The city is linked to an important medieval drama cycle. ${ }^{10}$ Some of the most continuous manorial records in England were produced by the Manor of Wakefield. ${ }^{11}$ Changes in local government over the centuries, especially in the 1970s, brought together under the authority of Wakefield Council a number of neighbouring towns with a keen sense of ownership over local heritage (Wakefield, Castleford, Pontefract, Ossett, Featherstone, Normanton, Knottingley, Hemsworth), as well as some rural mining villages. The region is famous for its agricultural history: much of Britain's rhubarb comes from near Wakefield; Pontefract was known for liquorice. ${ }^{12}$ The whole area was hard-hit by the collapse of the coal industry in the 1980s, and some of its communities are still identified by the government as relatively deprived based on levels of income, employment, health, education, crime, access to services and living environment. ${ }^{13}$ Nevertheless, the region is much recovered economically;

9. These events are described at: Wellcome Trust. "Guest post: You are what you ate". Wellcome Trust. 27 July 2016 <http://blog.wellcome.ac.uk/2010/08/10/guest-post-you-are-what-you-ate/>; University of Leeds; University of Bradford; Wakefield Council. "From possets to pies: alcohol and pastry-making through time". You are what you ate. 27 July $2016<$ http://www.leeds.ac.uk/yawya/news/news-from\% 20 possets \%20to\%20pies.html>.

10. Mayes, Philip; Butler, Lawrence; Johnson, Shirley, eds. Sandal Castle Excavations, 1964-1973: A Detailed Archaeological Report. Wakefield: Wakefield Historical Society, 1983; Ian Roberts. Pontefract Castle. Wakefield: West Yorkshire Archaeology Service, 1990; Churches Regional Commission for Yorkshire and Humber. "Sacred Places in Wakefield District". Old.Wakefield.Anglican.Org. 10 June $2016<$ https://www. yumpu.com/en/document/view/45010254/sacred-places-wakefield-district-diocese-of-wakefield>; Meredith, Peter, ed. The Towneley Cycle. Leeds: School of English, 1990-1991 (2 volumes); Haigh, Philip. The Battle of Wakefield 1460. Stroud: Sutton, 1996.

11. The court rolls (1274-1925) belong to the Yorkshire Archaeological Society but are housed in the Brotherton Library, University of Leeds. For published rolls, see: Yorkshire Archaeological Society Record Series 29, 36, 57, 78, 109 (1901-1945); for more information: Yorkshire Archaeological \& Historical Society. "Wakefield Court Rolls". The Wakefield Court Rolls Section of the Yorkshire Archaeological $\theta$ Historical Society - YAHS. 10 June 2016 <http://www.wakecourtroll.yas.org.uk>.

12. Foust, Clifford. Rhubarb: the Wondrous Drug. Princeton: Princeton University Press, 1992: 237-238; Chartres, John. "A Special Crop and its Markets in the Eighteenth Century: the Case of Pontefract Liquorice", People, Landscape and Alternative Agriculture: Essays for Joan Thirsk, Richard Hoyle, ed. Exeter: Agricultural History Society, 2004: 114-132.

13. For maps of the region based on the 2010 Index of Multiple Deprivation, see: Yorkshire and Humber Public Health Observatory. "Maps of deprivation for Yorkshire and Humber districts". Yorkshire 
thousands of people visit during Wakefield's Food, Drink and Rhubarb festival (February) and the Pontefract Liquorice Festival (July). Since the project began, Castleford has a new museum, Pontefract museum has been redesigned, Pontefract Castle has a new visitor centre and Wakefield itself has seen its main museum moved to a new purpose-built site and the opening of the Hepworth, a prestigious new art gallery. There is also continued support for the National Coal Mining Museum and the Yorkshire Sculpture Park, both located in the region. ${ }^{14}$ These sites demonstrate the commitment of Wakefield Council to heritage and culture as integral to regional development and help to explain the Council's support for You Are What You Ate. ${ }^{15}$ Although there have been closures due to the recent recession, with the especially sad loss of Clarke Hall Educational Museum, located in a $17^{\text {th }}$ century house that had been a venue for our earlier workshops because of its period kitchen and visitor facilities, the district has retained an extensive network of libraries, schools and museums. From the perspective of the university academics involved in the project, working with the senior cultural officers of a district council provided unprecedented access to communities, which simply would not have been possible without the collaborative partnership.

\section{The Project and its Management}

“The applicants are to be commended for their enthusiasm and collegiality". ${ }^{16}$

The key to success of this project was the collegiate, face-to-face working practices established from the start. Associated with these practices was the early appointment of an administrator, Fiona Blair, who invested a great deal of energy, doing far more than the two days a week she was employed on the project. It is worth noting that the grant did not cover the time of any already salaried project member and was dependent on personal commitment. As many as possible of the core team members: the three authors (Mcleery, Buckberry, Shearman), Maya Harrison, Gary Williamson and Fiona Blair, met at first fortnightly and then monthly as the project progressed in order to report on the various types of activities. Each type

and Humber Health Intelligence. 10 June 2016 <http://www.yhpho.org.uk/default.aspx?RID=110329>. We were pleased to be able to run events in some of the more deprived areas such as Castleford and Hemsworth.

14. See for details: Experience Wakefield. "Home". Experience Wakefield. 10 June $2016<$ http://www. experiencewakefield.co.uk/>.

15. For Wakefield's core strategy, see: Wakefield Council. "Core Strategy". Wakefield Council. 10 June 2016 <http://www.wakefield.gov.uk/residents/planning/policy/local-plan/core-strategy>. For the role of 'resilient communities and supportive environments' in improving health and well-being, see: Health 2020: A European Policy Framework and Strategy for the 21st Century. Copenhagen: World Health Organization, 2013.

16. Anonymous reviewer of the Wellcome Trust, attachment in e-mail, March 17, 2010. 
of activity was coordinated by one member of the core team: osteology workshops (Buckberry), schools and family/youth workshops (Shearman), exhibitions (Harrison), festivals/talks/website ( $\left.\mathrm{M}^{\mathrm{c}} \mathrm{Cleery}\right)$. All the activities were inter-linked: talks and family activities related to exhibitions; market stalls promoted exhibitions; the osteology workshops varied content depending on the exhibition.

There is very little scholarship on partnership working between museums and universities, but one study identifies potential barriers to such partnerships as "different methodologies, terminologies and scholarly practices" and "different priorities and expectations". ${ }^{17}$ Some of these issues came up in our long, sociable meetings, but we generally found them to be productive and interesting differences rather than barriers. Communication was greatly aided by the fact that Vicky Shearman had previously been a research scientist in a higher education institution and has a keen personal and professional interest in medieval studies and living history. From a museum perspective, our project was always unusual, especially our exhibitions, because rather than deriving our themes from the museum collections themselves, we brought the themes ready-made to the collections and hoped to find sufficient appropriate artefacts. One result was that displays were rather text-heavy by comparison with best museum practice, although lighter than they might have been had only Buckberry and $\mathrm{M}^{\mathrm{C}}$ Cleery been involved; we learned a great deal from Shearman and her colleague Maya Harrison. ${ }^{18}$

Recently, a few historians have expressed some rather ambiguous attitudes towards museums. For example, Ludmilla Jordanova is very dismissive of the role of museums in an influential book, writing, in an unfortunate turn of phrase as far as our own project is concerned, that "museums work in insidious ways. The past they present is highly refined, in the manner of manufactured foods". ${ }^{19}$ The present authors completely reject this negative attitude. Other historians seem to

17. The editors' introduction to Museums and Higher Education Working Together: Challenges and Opportunities (Speight, Catherine; Boddington, Anne; Boys, Jos. "Introduction". Museums and Higher Education Working Together: Challenges and Opportunities, Anne Boddington, Jos Boys, Catherine Speight, eds. Farnham: Ashgate, 2013: 13-14). Also thoughtful is: Collins, Peter. "Museums: the Resilience Illusion". LinkedIn. 18 December 2015. 12 May 2016 <https://www.linkedin.com/pulse/museums-resilience-illusion-petercollins?articleId=9220223271599469290>, especially the concept of the 'funder bubble' in which both museums and funders (and we would add funded academics) need partnerships but for very different reasons.

18. Pearce, Susan. Museums, Objects and Collections: A Cultural Study. Leicester: Leicester University Press, 1992; Dean, David. Museum Exhibition: Theory and Practice. London: Routledge, 1994. As the project progressed, both $\mathrm{M}^{\mathrm{c}}$ Cleery and Buckberry changed their writing style, with fewer editing stages necessary for the later exhibitions. This process was an enlightening educational experience. On the planning of our third exhibition, see: McCleery, Iona. "Exhibition planning for beginners: from idea to execution". Blog. Life from a Wellcome Trust perspective. 27 July 2016 <http://blog.wellcome.ac.uk /2013/04/30/exhibitionplanning-for-beginners/>.

19. Jordanova, Ludmilla. History in Practice. London: Hodder Arnold, 2006: 127; de Groot (De Groot, Jerome. Consuming History...: 116-118, 236-247), is more positive, but focuses on the economic rather than educational roles of museums. Faye Sayer (Sayer, Faye. Public History: A Practical Guide. London: Bloomsbury, 2015: 22-45), seems to view museums mainly as places of employment for history graduates. For more positive approaches, see: Samuel, Raphael. Theatres of Memory. London: Verso, 19941997 (2 volumes); Keen, Hilda; Martin, Paul, eds. The Public History Reader. London: Routledge, 2013. 
feel that they have lost ground to museums and the media, wishing to reclaim a perceived former central role in the public's reception of the past. ${ }^{20}$ There has been very little effort to analyse critically the often very fruitful collaborations that academics have long had with non-Higher Education institutions. Some of these partnerships were developed more recently in order to demonstrate the impact of academic research for the Research Excellence Framework (REF 2014) imposed on British universities. ${ }^{21}$ That does not make them any less fruitful. You Are What You Ate originally arose independently in 2009-10, long before the impact agenda of REF 2014 was understood. However, it eventually became an 'impact case study' for the School of History at the University of Leeds, and part of the 'impact template' for the Department of Archaeological Sciences at the University of Bradford. ${ }^{22}$ Compared to historians, archaeologists appear to be more reflective about the relationships between universities and communities, social media, the commercial sector and museums. ${ }^{23}$ The discipline of Museum Studies has, of course, long pondered relationships between museums, audiences, education and communities. ${ }^{24}$ In the end, Buckberry and $\mathrm{M}^{\mathrm{c}}$ Cleery found museum approaches to be both sensible and

There has long been a debate about the uses and users of the past. See for example: Lowenthal, David. The Past is a Foreign Country. Cambridge (UK): Cambridge University Press, 1985.

20. Tosh, John. "Public History, Civic Engagement and the Historical Profession in Britain". History, 99/345 (2014): 191-212; Guldi, Jo; Armitage, David. The History Manifesto. Cambridge (UK): Cambridge University Press, 2014; revised online version: Guldi, Jo; Armitage, David. "The History Manifesto". Cambridge University Press. 10 June 2016 <http://historymanifesto.cambridge.org/>; and the discussion in American Historical Review: Cohen, Deborah; Mandler, Peter; Armitage, David; Guldi, Jo. "Exchange: On The History Manifesto". American Historical Review, 120/2 (2015): 527-554.

21. Collini, Stefan. What Are Universities For? London: Penguin, 2012: 168-177; Sayer, Derek. Rank Hypocrisies: the Insult of the REF. London: Sage, 2015; King, Laura; Rivett, Gary. “Engaging People in Making History: Impact, Public Engagement and the World Beyond the Campus". History Workshop Journal, 80 (2015), 218-233. See also: Research Excellence Framework 2014. "Research Excellence Framework". REF2014. 6 August $2015<$ http://www.ref.ac.uk/>.

22. REF2014 required us to disaggregate our collaborative project. See for Leeds: McCleery, Iona. “Impact case study (REF3b). Enhancing adults' and children's awareness of healthy eating today by using research into medieval ideas of healthy lifestyle and diet". REF2014. 10 June 2016 <http://impact.ref.ac.uk/ casestudies2/refservice.svc/GetCaseStudyPDF/6387>. For Bradford: Archaeological Sciences, University of Bradford. "Impact Template". REF2014. 6 August $2016<$ http://results.ref.ac.uk/DownloadFile / ImpactTemplate/pdf?subId=26>.

23. Stone, Peter; Planel, Philippe, eds. The Constructed Past: Experimental Archaeology, Education and the Public. London-New York: Routledge-English Heritage, 1999; Waterton, Emma; Smith, Laurajane. Heritage, Communities and Archaeolog. London: Bloomsbury, 2009; Moshenka, Gabriel; Dhanjal, Sarah. Community Archaeology: Themes, Methods and Practices. Oxford: Oxbow, 2011; Meyers Emery, Katy; Killgrove, Kristina. "Bones, Bodies, and Blogs: Outreach and Engagement in Bioarchaeology". Internet Archaeology, 39 (2015): <http://dx.doi.org/10.11141/ia.39.5> (10 June 2016).

24. Manfredi, Leanne; Reynolds, Rebecca. "Tales from the Coalface", Museums and Higher Education Working Together: Challenges and Opportunities, Anne Boddington, Jos Boys, Catherine Speight, eds. Farnham: Ashgate, 2013: 135-145; Watson, Sheila. Museums and their Communities. London: Routledge, 2007; Hooper-Greenhill, Eilean. Museums and Education; Purpose, Pedagogy, Performance. London: Routledge, 2007; Anderson, David. A Common Wealth: Museums and Learning in the United Kingdom. London: Department of National Heritage, 1997. See also the resources of the Group for Education in Museums at: Group for Education in Museums (GEM). "Welcome to GEM". GEM. The voice for heritage learning. 21 July 2016 <http://www.gem.org.uk/index.php>; and the Museum Association's education 
innovative. In practice, what we all found to be the greatest barrier was time: we all had many other commitments. Timetabling was a major issue: the university timetable does not synchronise well with the rhythms of the school year. Museums are aligned with it, but the project's numerous in-school workshops - which greatly increased Wakefield's outreach provision in the long-term- required new working methods in order to reconcile teachers' needs and museum staff capacity.

It is not possible to analyse all our activities here and how they were planned. We will focus on the major milestones that were our three large exhibitions and our schools workshops. ${ }^{25}$ The exhibitions ran in Wakefield Museum (Sugar $\theta$ Spice and All Things Nice, 2011; Food for All Seasons, 2013) and Pontefract Museum (The Dark Side of Eating, 2012). ${ }^{26}$ These exhibitions drew on different ranges of expertise. For example, global trade, science of taste, feasting and dental health were prominent in 2011; nutritional disease was the focus in 2012; medieval Wakefield and the history of food dominated in 2013. In accordance with museological research, as well as with the practical experience of Shearman and Harrison, we felt it was very important to respect the wishes of local people to see their museums' own collections in temporary exhibitions. ${ }^{27}$

In order to combine these artefacts with our pre-conceived themes we had to be very flexible in our approach to the topic, borrowing imaginatively from other collections. In 2013 it was a great coup to bring some Wakefield Court Rolls back to Wakefield for the first time since the 1920s as well as Books of Hours donated to the University of Leeds by Lord Brotherton (died 1930), a former member of parliament for Wakefield. ${ }^{28}$ Also that year we displayed agricultural implements and medieval pottery, items that are sometimes difficult for modern urban audiences to appreciate. In 2012 we brought past and present together by displaying an early $20^{\text {th }}$ century weighing machine used at a 'seaside school' run by Wakefield Council on the Yorkshire coast for many years from the 1930s for poor, malnourished and sick children, ${ }^{29}$ alongside medieval bones excavated from Pontefract, curated by

agenda at: Museum Association. “The education agenda". Museum Association. 21 July $2016<$ http:// www.museumsassociation.org /campaigns/museums-and-the-education-agenda>.

25. The osteology workshops are discussed in detail in: Buckberry, Jo; Ogden, Alan; Shearman, Vicky; McCleery, Iona. "You Are What You Ate: Using Bioarchaeology to Promote Healthy Eating", Trends in Biological Anthropology, Karina Gerdau-Radonić, Kathleen McSweeney, eds. Oxford: Oxbow, 2015: I, 100111 .

26. University of Leeds; University of Bradford; Wakefield Council. "Exhibitions". You are what you ate. 27 July 2016 <http://www.leeds.ac.uk/yawya/events/exhibitions/exhibitions.html>.

27. For engagement with Wakefield collections, see: Johnstone, Christine. "Your Granny Had One of Those! How Visitors Use Museum Collections", History and Heritage: Consuming the Past in Contemporary Culture, John Arnold, Kate Davies, Simon Ditchfield, eds. London: Donhead, 1998: 67-77. See also: Nielsen, Jane K. "The Relevant Museum: Defining Relevance in Museological Practices". Museum Management and Curatorship, 30 (2015), 364-378.

28. Donnelly, James. "Brotherton, Edward Allen, Baron Brotherton (1856-1930)", Oxford Dictionary of National Biography, Colin Matthew, Brian Harrison, eds. Oxford: Oxford University Press, 2004: VII, 959960.

29.McLeod, John. Seaside School: 60 Years of the Wakefield School in Hornsea. Castleford: Yorkshire Art Circus Ltd, 1999. 
the University of Bradford. The bones were used to demonstrate the effects of rickets (Vitamin D deficiency) and scurvy (Vitamin C deficiency) on a child, and osteoarthritis of the knee (a condition common in obese individuals) on an adult. We displayed a video of these and similar diseased bones produced as part of Digitised Diseases, a separate research project at Bradford. ${ }^{30}$

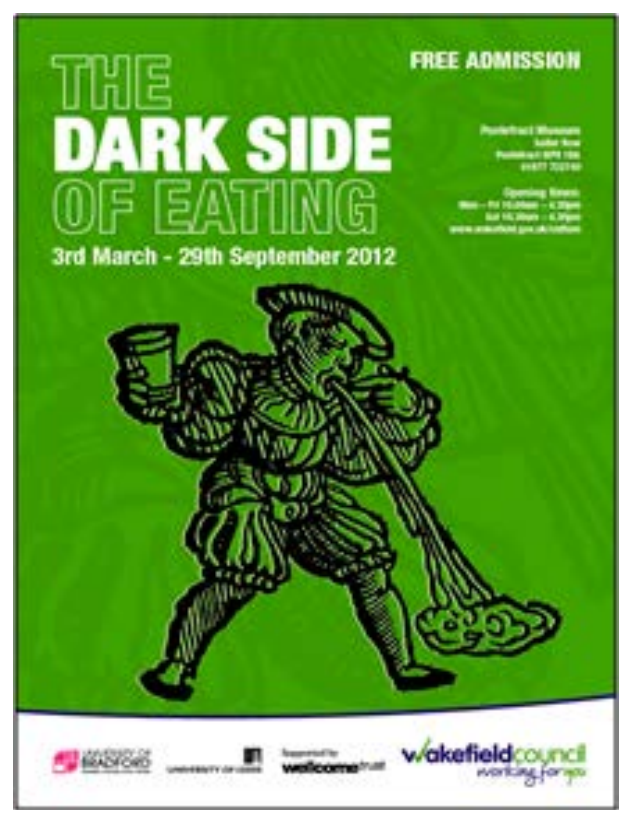

Illustration 1. POSTER FOR THE DARK SIDE of Eating, Pontefract Museum 2012, INCORPORATING AN IMAGE FROM THE WELLCOME LIBRARY.

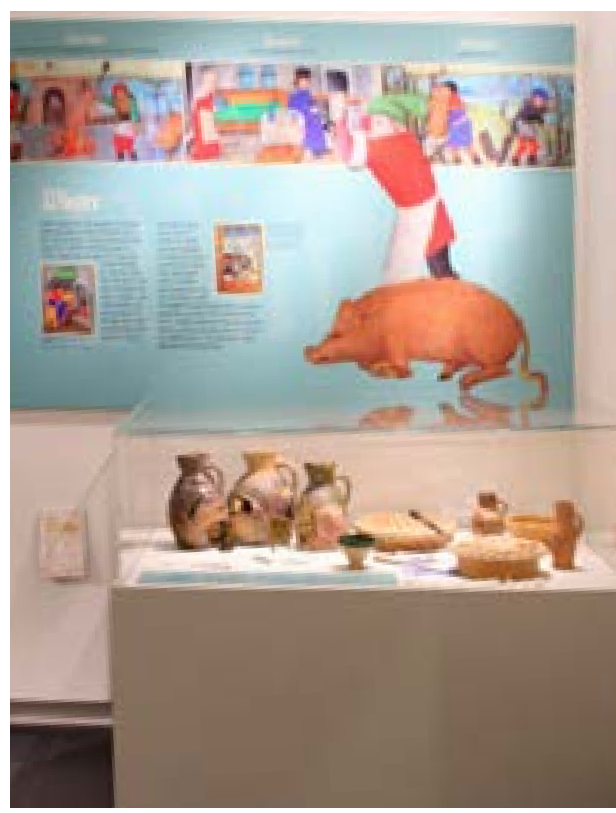

ILLUSTRATION 2. A CONTEXTUAL SHOT OF FOOD FOR All SEASONS (2013), InCORPorating the MUSEUM COLLECTIONS, REPRODUCTION FOOD AND IMAGES FROM: LEEDS UNIVERSITY LIBRARY. BROTHERTON MANUSCRITS, Ms. 1 AND 9. PICTURE BY IONA M Cleery.

Due to the time constraints set by other responsibilities and the expertise required, we decided that many of our schools activities would be delivered by trained educators, both experienced freelancers and specialised museum outreach staff, with whom we worked closely at the design stage. This decision is the main reason why we were able to visit so many schools and clubs in the region, with often repeat visits to schools and the ability to adapt workshops over time. One of the advantages of a long-term, well-funded

30. 'Digitised Diseases' is an open access resource developed by the University of Bradford, the Museum of London Archaeology and the Royal College of Surgeons of England, supported by the JISC Content Programme: University of Bradford; Museum of London Archaeology; Royal College of Surgeons of England. "The project". Digitised Diseases. 7 August $2016<$ http://www.digitiseddiseases.org/alpha/>. 
project is that it was possible to try riskier activities that would not normally be costeffective for a museum service. For example, we ran workshops for Key Stage 1 pupils (aged 4-6) and at Special Educational Needs schools, something not previously possible on this scale. Youth worker Jane Howroyd also engaged groups of young people about to be excluded from school and a hard-to-reach 'detached' group that meets in a park. ${ }^{31}$ Youth work of this kind was not originally part of the budget, but savings elsewhere allowed us to be flexible in accordance with perceived need.

We decided to increase our youth work largely as a result of the monitoring we did of all our activities, which made it apparent that we were not engaging the 13-19 agegroup much at all. Young people of secondary-school age are much less likely than younger children or adults to attend a museum or family-oriented fair and they are more difficult to engage in evaluation exercises. ${ }^{32}$ It is harder for museums to access secondary schools due to curriculum and timetable constraints, although we did manage some activities with three schools in the 11-18 age range. In contrast, we engaged with sixty-one of Wakefield's primary schools (over 50\%) either in-school, in the museum, or on the Bradford university campus (some schools did all three). Primary schools seem more attuned to the opportunities afforded by Wakefield's medieval heritage, especially through commemoration of the $550^{\text {th }}$ anniversary of the Battle of Wakefield in 2010 . This interest may be because the National Curriculum for primary school education in history at Key Stage 2 (ages 7-11) requires a local history component. ${ }^{33}$ We found that our free workshops reinforced or made a good introduction to other history topics (this was so much the case with the Tudors that in the final year we shifted from a Battle of Wakefield to a $16^{\text {th }}$ century scenario). ${ }^{34}$ We deliberately linked our project to the National Curriculum for Science and also for Personal, Social and Health education, as well as identifying problem-solving and team-working benefits. Teachers commented on these links when asked to evaluate the immediate impact of the workshop:

- "good support for our healthy schools week";

- "linked to our workshop on the Battle of Wakefield";

- "a nice opener to our class topic on healthy eating";

- "in school will link [to] environment/sustainability. It really challenged thinking/ deduction";

31. Shearman, Vicky. "Museum Practice: Engaging Teens with Healthy Eating". Museum Association. 12 December 2014. 22 July 2016 <http://www.museumsassociation.org/museum-practice/ teenagers/12122014-wakefield-museums>.

32. Out of 335 children's questionnaires collected at markets and fairs in 2011-2014, only nineteen came from young people aged $12-15(5.4 \%)$. Out of 244 adult questionnaires collected over the same period, only seven fell in the $16-19$ age range $(2.9 \%)$.

33. The curriculum changed in September 2014, but still includes a local study. The previous curriculum is archived at: Department of Education. "Primary National Curriculum Until 2014". The National Archives. 10 June 2016 <http://webarchive.nationalarchives.gov.uk/20131202172639/http:// www.education. gov.uk/schools/teachingandlearning/curriculum/primary $>$.

34. In 2011-2013 the scenario was that Joan or Bess (educators in costume) passed through the area seeking food for injured soldiers; the children were enlisted to help her budget the weekly menu in order to produce a balanced diet; they were encouraged to link exercise and dietary intake, invited to guess the identity of mystery cooking utensils, and asked to make a medieval green sauce. In 2013-2014, the scenario changed to Bess helping to feed villagers recovering from sweating sickness. 
- "as we embark on a topic about Tudor exploration, we were given a lot of background information in a way that interested the children and captured their imagination";

- "continued interest in medicine following work on Florence Nightingale";

- "[the children's] previous knowledge was shown as the content related to prior learning. They were very interested in the food aspect and were keen to do more practical things";

- "excellent reinforcement of one of our earlier science topics". ${ }^{35}$

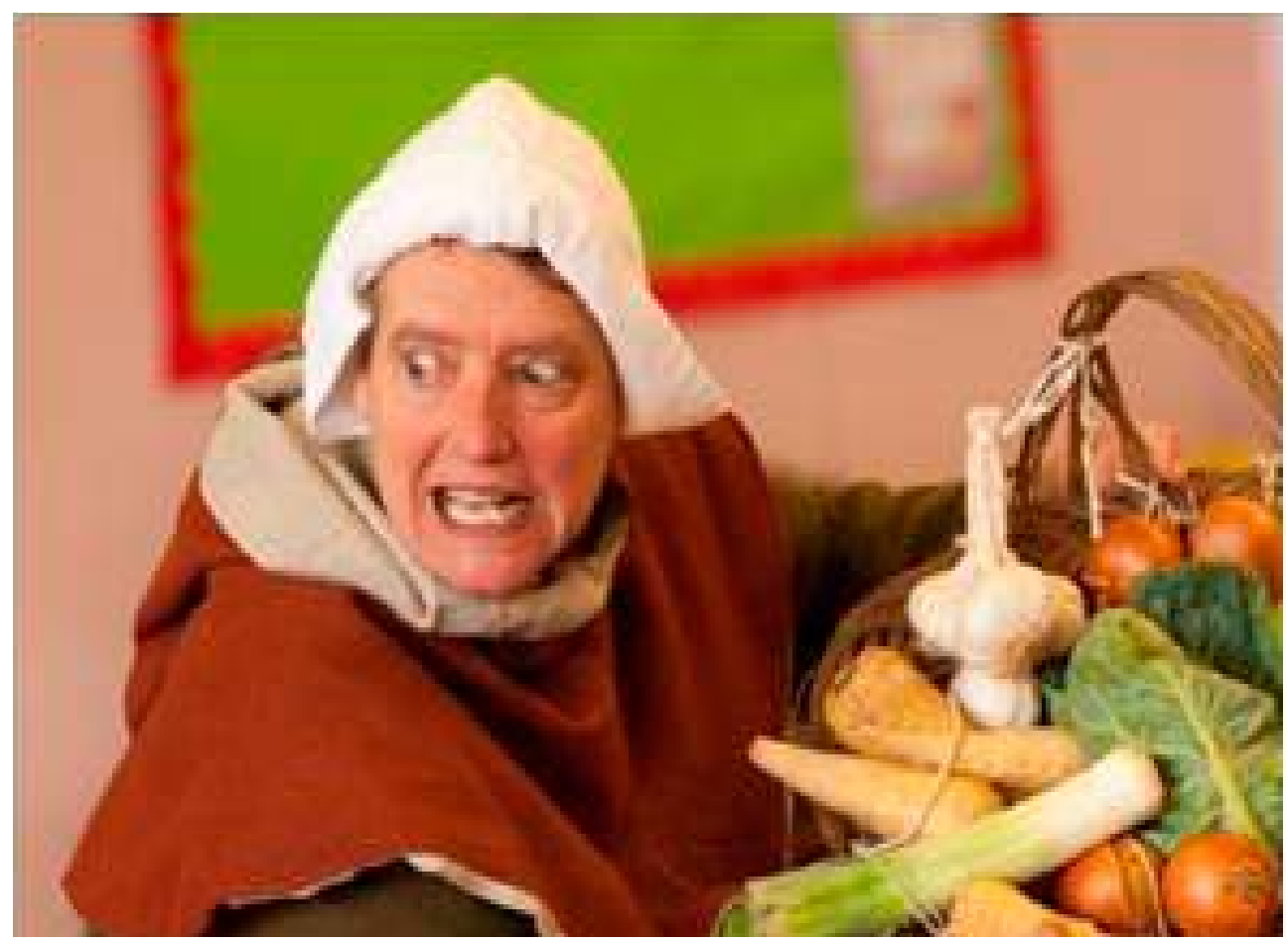

Illustration 3. 'Joan' (SallyAnn Burley) in action at a school in May 2011. Picture by Tony GLossop.

35. Anonymous comments collected after workshops on June 22, 2011 , July 8, 2011, September 28, 2011 , June 18, 2012, November 15, 2012, November 16, 2012, June 21, 2013 and January 15, 2014. 
When asked to comment on the immediate impact of the children's osteology workshops, which were run by a team of bioarchaeological staff and students and took place in a laboratory at the University of Bradford (free transport provided), teachers found them particularly aspirational for the children:

- "it was an opportunity to visit a university which will be thought provoking. It also encouraged discussion and co-operation";

- "[they acquired] a greater understanding of how diet effects our bones and teeth. Perhaps the children will think about their choices. This session has been inspiring, enlightening children to opportunities for further education";

- "fantastic to work in a university lab, inspired them to think about how science plays a large part in their daily lives". ${ }^{36}$

Our experience of running these workshops suggests that their success was due to making links with more than one part of the curriculum; being flexible; providing practical new learning experiences that nevertheless reinforced the teachers' programme of activities and encouraged progression; and having dedicated trained individuals to deliver them. Some schools were engaged with two or three times in this one activity, suggesting that the teachers were keen to repeat the experience from one year to the next. Nevertheless, we are aware that our success was also closely linked to the fact that workshops were free. The project covered all running costs and provided transport where necessary, so this probably explained the greater participation of some schools in Wakefield's museum services during the project, particularly from the more deprived and distant areas in the south-east of the region. Although being free at the point of delivery is a key part of the Wellcome Trust's public engagement ethos, it does mean that sustainability becomes very difficult once the external funding ends.

As the project drew to a close, we thought very hard about the issue of sustainability. We had already realized that we could not offer the children's osteological workshops in Bradford at the same frequency as the in-school workshops because of the time pressures on staff and students in a busy professional laboratory. We therefore decided in the final year of our project to develop 'Skeleton Secrets', a museum-based osteological experience run by museum staff in Wakefield. This workshop was designed to be sustainable into the future but was a high-risk venture requiring investment that would not have been possible without the Wellcome Trust's support (sturdy plastic skeletons, expert adaptation of them by Alan Ogden at the University of Bradford, staff training). We took the risk of offering the workshop to schools without covering the cost of transport to the museum. The result was a lower take-up but not significantly so. There were twelve workshops for eleven schools -301 childrenat the museum during spring/summer 2014 as opposed to sixteen Tudor food workshops run at nine schools -439 children- over the same period. Clearly more children can be engaged with in schools than out of them because of transport

36. Anonymous teachers' comments on questionnaires collected after sessions on May 22, 2012, June 19, 2013 and June 12, 2014 respectively. For more detailed evaluation of the osteology workshops, see: Buckberry, Jo; Ogden, Alan; Shearman, Vicky; Mcleery, Iona. “You Are What You Ate...": 100-111. 
costs. On the other hand, some schools engaged with the project for the first time at the museum. We are pleased to say that both 'Skeleton Secrets' and the Tudor workshops continued to be booked throughout 2015 and beyond. The latter has also inspired $19^{\text {th }}$ century and 1940 s versions. In the future, we would think carefully before making all activities entirely free as it can make sustainability difficult to achieve after the end of a project. The same issue applies with adult outreach; a small fee for talks and conferences may make them viable for longer.

\title{
4. Evaluation Methods
}

\begin{abstract}
“Evaluation is a process of collecting evidence and reflection that will help you understand the dynamics and effect of your work, and help you with your next public engagement project". ${ }^{37}$
\end{abstract}

Evaluation is an essential part of any project. Some of the results of our evaluation have already been seen in relation to teachers' responses and our perceived need for more youth work. Evaluation is often seen as something that has to be done just to fulfil funding and institutional requirements. However, projects do need to prove that money was well-spent, in order to secure further investment in the same or a future project. A more neglected aspect of evaluation is the crucial need for team members to evaluate their own activities throughout a project in order to assess the design of sessions and the effectiveness of teamworking. ${ }^{38}$ This is particularly important in a long-term project where activities are intended to be repeated multiple times: for example, our schools workshops and market stalls. They are unlikely to be got right the first time, but without evaluation it is difficult to interpret any problems that might arise. In addition, the confidence-boosting role of positive feedback should not be under-estimated especially where university staff and students are new to engaging with communities!

There are many different ways to evaluate the success of a project, but it can sometimes be challenging to capture the views and opinions of a diverse audience,

\footnotetext{
37. National Co-ordinating Centre for Public Engagement. "Evaluating public engagement". National Co-ordinating Centre for Public Engagement. 21 July $2016<$ https://www.publicengagement.ac.uk/plan-it/ evaluating-public-engagement $>$.

38. For an overview of evaluation and other resources, see the National Co-ordinating Centre for Public Engagement website: National Co-ordinating Centre for Public Engagement. "Home". National Coordinating Centre for Public Engagement. 21 July $2016<$ https://www.publicengagement.ac.uk/>. For the Wellcome Trust's guidelines, see: Wellcome Trust. “Public Engagement”. Wellcome Trust. 21 July 2016 <http://www.wellcome.ac.uk/Funding/Publicengagement/ Application-information/index.htm>; and also: Turney, Jon, ed. Engaging Science: Thoughts, Deeds, Analysis, Action. London: The Wellcome Trust, 2006. Online version: Turney, Jon, ed. "Engaging Science: Thoughts, Deeds, Analysis, Action". Wellcome Trust. 21 July 2016 <https://issuu.com/wellcome-trust/docs/engagingscience>.
} 
particularly at a one-off event: how can we evaluate "powerful memories and infectious enthusiasm?" 39 Project evaluation must include reflection on evaluation methods. Not only can some forms of evaluation, e.g. questionnaires, alienate sectors of the community, who might feel that they have become research objects, but it may be inappropriate with some vulnerable groups and raises numerous ethical issues. ${ }^{40}$ We found that there is a very fine line between evaluating the benefits of the dissemination of the findings of dietary research and the carrying out of actual dietary research (both of which ideally require the collection of personal information from participants on daily food intake, weight, income, age and ethnicity). Although done through an historical lens, the biomedical research that we shared focused on the constituents of a balanced diet, patterns of nutritional health and methods of improving health education. ${ }^{41}$ Although we did our best not to cross the fine line between research and evaluation -partly by not collecting most of the aforementioned personal information- it meant we had to focus on immediate and short-term outcomes because we could not do follow-up activities with the same group of people. In particular, we focused on our original aim of encouraging personal 'reflection' on diet, something that is possible to capture through immediate questioning. Nevertheless, throughout the project there was some tension between our dissemination aims and how the project was perceived: that is as a healthy eating campaign (a form of intervention specifically excluded from the Wellcome Trust's funding call). As healthy diet was the focus of the underpinning research, both modern and medieval, we did not see this perception as a problem.

The evaluation methods used for this project were both quantitative and qualitative. We decided not to pay for external evaluation, although this is something that could suit smaller projects. Our methods included the following:

- Calculating engagement numbers/'footfall' at each event or activity;

- Gathering data on website usage: number of hits, key search words, patterns and spikes; ${ }^{42}$

- Questionnaires tailored for different events and groups (e.g. adult or child participants; teachers, youth-workers; schools workshops, market stalls, talks or osteology workshops);

39. Stone, Peter; Planel, Philippe, eds. The Constructed Past...: 9 ("introduction").

40. At the External Engagement in the Arts and Humanities conference held at the University of York on 19 May 2014, Professor Brendan Stone (University of Sheffield) explained how his attempt formally to evaluate what he felt had been a successful series of workshops run with residents of a high security mental health hospital was a self-confessed disaster because the participants resented the sudden shift in perspective when he asked them to fill in a questionnaire.

41. We drew in particular on the work of the Nutritional Epidemiology Group at the University of Leeds, run by project member Janet Cade. The group's research includes improving the verifiability of relationships between diet and disease, especially more accurate gathering of data via questionnaires and other methods. See: University of Leeds. "Faculty of Mathematics and Physical Sciences. School of Food Science and Nutrition". University of Leeds. 27 July $2016<$ http://www.food.leeds.ac.uk/research/sections/ nutrition-and-public-health/nutritional-epidemiology.html>.

42. Although the website cannot be analysed here, it had 40,690 unique visitors by December 2014 . 
- Participants were asked to complete comments cards or write in visitor books (exhibitions);

- Focus group/interviews (especially linked to exhibitions);

- Photographs;

- Analysis of children's artwork (produced often on the questionnaires);

- Collecting media references to events. ${ }^{43}$

The university academics involved in the project were not previously familiar with evaluation methods, but since 2000 museums have used a system of evaluation known as Generic Learning Outcomes (GLOs). The GLOs were part of a framework called Inspiring Learning for All, which was developed at the University of Leicester for the now defunct Museums, Libraries and Archives Association (MLA). ${ }^{44}$ This framework has not gone uncontested as it is based on a constructivist approach that assumes learning is always beneficial (in a way that can be seen as paternalistic) and always bound to take place albeit in fluid, overlapping and subjective ways. The assumption is that all participants and museum visitors build on prior knowledge and individual perceptions. Eventual learning cannot be predicted especially as few visitors have a specific objective in mind when they participate in something; responses as a result are highly subjective and difficult to interpret. GLOs are hard to analyse because the enjoyment, skills and attitudes that they document are so closely related: learning a new activity can be fun, and indeed enjoyment is likely to deepen the learning, but it is hard to prove this without knowledge of prior learning and attitudes. GLOs work better for quantitative analysis where there are large numbers of participants whose responses have been coded, but they still yield rich insights at the level of individual response. ${ }^{45}$ On the one hand, if specific learning outcomes cannot be identified, it remains difficult for cultural institutions objectively to prove their specific educational impact. On the other hand, GLOs have been described as "sympathetic, inclusive and open-minded" and better

\footnotetext{
43. For media references, see: University of Leeds; University of Bradford; Wakefield Council. "In the news: Media coverage of the project". You are what you ate. 27 July $2016<$ http://www.leeds.ac.uk/yawya/ news/In\%20the\%20news.html >.

44. For background see a report commissioned by the Research Centre for Museums and Galleries, University of Leicester: Graham, Jo. "Evidencing the Impact of the GLOs". University of Leicester. January 2013. Learning Unlimited. 21 July 2016 <http://www2.le.ac.uk/departments/museumstudies/rcmg/ projects/evidencing-the-impact-of-the-generic-learning-outcomes $>$. A re-launched framework can now be found at: Arts Council of England. "Inspiring Learning for All". Arts Council. 21 July $2016<$ http:// www.artscouncil.org.uk/advice-and-guidance/inspiring-learning-all-home-page>.

45. Graham, Jo. "Evidencing the Impact..."; Hooper-Greenhill, Eilean. Museums and Education...: 44-62 (chapter 11: "Learning in the Post Museum"); Pontin, Kate. "Understanding Museum Evaluation", The Responsive Museum: Working with Audiences in the Twenty-First Century, Caroline Lang, John Reeve, Vicky Woollard, ed. Aldershot: Ashgate, 2006: 117-127; Brown, Stephen. “A Critique of Generic Learning Outcomes". Journal of Learning Design, 2/2 (2007): 22-30; Kling, Sofia. "Assessing Heritage Outcomes: How we do it and Why". Relevant Museum.wordpress. 21 July $2016<$ https://relevantmuseum.files. wordpress.com/2013/10/kling-sofia-assessing-heritage-learning-outcomes-how-do-we-do-it-e28093and-why.pdf> (Paper presented at: Heritage, Regional Development and Social Cohesion conference, Sweden, June 2010).
} 
than other methods at "capture[ing] what actually goes on at cultural heritage institutions". ${ }^{46}$ In fact, most methods of evaluating cultural activities are open to critique for the simple reason that events or visits are difficult to evaluate in a quantifiable and reportable way because of the subjective and ad hoc nature of the experience. François Matarasso's influential positive appraisal of the social impact of participation in the arts in several countries in 1997 met with similar critique. ${ }^{47}$ The requirement of British university departments to demonstrate the impact of their research as part of REF 2014 also encountered difficulties with proving change in attitudes and public benefit. ${ }^{48}$

Despite these problems and debates, the decision of some local councils, like Wakefield, to continue to maintain museums throughout the recession, despite cuts in central government and charitable funding in many areas, suggests that culture and heritage are widely accepted as both a means to and a sign of economic regeneration. Museums have therefore been able to persuade policy makers and stakeholders of their value, but evaluate what they do continually, focusing now much more on Generic Social Outcomes (GSOs), another part of the Inspiring Learning for All framework, which aim to strengthen communities and improve health and well-being. ${ }^{49}$ These are even more difficult to identify and code but in recent years they have contributed to an explosion of healthrelated activities and exhibits across the country, a movement to which the You Are What You Ate obviously belongs. ${ }^{50}$ The university-based academics working on the You Are What You Ate project felt that museum-developed methods of evaluation offered by far and away the best method of gathering and analysing data on our activities. Buckberry and $\mathrm{M}^{\mathrm{c}} \mathrm{Cleery}$ have greatly appreciated being able to learn these skills from Shearman and her team.

We designed our questionnaires according to the five categories of GLOs: knowledge and understanding; skills; attitudes and values; enjoyment, inspiration, creativity; activity behaviour and progression, making sure to provide a mixture of quantitative and qualitative questions. For children's questionnaires

46. Kling, Sofia. “Assessing Heritage Outcomes...": 11, 12.

47. Matarasso, François. Use or Ornament? The Social Impact of Participation in the Art. Stroud: Comedia, 1997; Merli, Paola. "Evaluating the Social Impact of Participation in Arts Activities". International Journal of Cultural Policy, 8 (2002): 107-118; Matarasso, François. "Smoke and Mirrors: a Response to Paola Merli's "Evaluating the Social Impact of Participation in Arts Activities". International Journal of Cultural Policy, 9 (2003): 337-346; Belfiore, Eleanor; Bennett, Oliver. "Rethinking the Social Impacts of the Arts". International Journal of Cultural Policy, 13 (2007): 135-151.

48. This observation is based on McCleery's experience of writing a REF case study. See also: Sayer, Derek. Rank Hypocrisies...: 28-29; King, Laura; Rivett, Gary. “Engaging People in Making History...": 218-233.

49. Arts Council of England. "Generic Social Outcomes". Arts Council. 21 July 2016 <http://www. artscouncil.org.uk/measuring-outcomes/generic-social-outcomes>.

50. Chatterjee, Helen; Noble, Guy. Museums, Health and Well-being. Farnham: Ashgate, 2013; Bodley, Alison. History to Health: Research into Changing Health Agendas for the UK Medical Collections Group. Leeds: Thackray Museum Leeds-UK Medical Collections Group-Arts Council England, 2012: 7-8, 18-22; online version: Bodley, Alison. "History to Health: Research into Changing Health Agendas for the UK Medical Collections Group". Thackray Medical Museum. 22 July 2016 <https://www.thackraymedicalmuseum. co.uk/ThackrayMuseum/media/Attachments/historytohealth.pdf>. 
it is important to provide space for drawings as these can also be analysed using GLOs (see illustration 4). In youth work we used very simple grid systems to indicate likes and dislikes. We did our best to capture oral feedback through written dictation (which seemed less intrusive than recording and more effective in a crowd). Often the richest material was never written down by participants themselves and sometimes impossible to capture.

We ran a focus group towards the end of the project, the content of which was recorded. Although a focus group is a more sustained evaluation activity that can provide evidence of prior learning, it can have its own problems. For example, participants are likely to be affected by the experience of being in the focus group. One participant, when asked which activity had been most enjoyable or interesting, responded: "Well my favourite event, really, is the whole event today... the actual event where we've all come and spoken about it", that is, the focus group itself. ${ }^{51}$ We found that the focus group prompted an interesting discussion about the relationship between food, poverty, life expectancy and health, partly prompted by the exhibition Food for All Seasons, but it was difficult to know what this meant for activity behaviour and progression. Some of the participants were much more interested in learning about $u s$ as researchers and how they could help or improve 'our' future activities. Through the GLOs and other methods it is possible to demonstrate the significance of "powerful memories and infectious enthusiasm", but capturing feedback really should not take the place of the actual activity or affect the formation of those memories. At the same time, public engagement is a two-way process that affects the development and attitudes of all people and institutions involved, including academic researchers, students and museum staff. Unfortunately, the current perceptions of 'impact' in UK universities reinforce older paternalistic models of public benefit that do not allow much room for collaboration, partnership or multi-way attitudinal and behavioural change.

51. Blair, Fiona, Focus Group, September 2014 (unpublished transcript); Krueger, Richard; Casey, Mary Anne. Focus Groups: a Practical Guide for Applied Research. Thousand Oaks: Sage, 2015. We originally wanted to do more focus groups, but in practice they are extremely difficult to organize. We provided participants with travel expenses and refreshments. 
P5

Git, 8years old

Sopte 2013

GLO

Knowetge and undersanding

Skils

Attitudes and he fing

Enigyment inspirtos, seretivity

Atwint betwisur progetrion

Description

Detailed drwing o bessin estume, hoding itens fom the workhop sesion Her pouch is derly shown, along with her

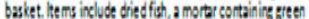

suce, herb salis and ather iters links to the wirchos.

Summary

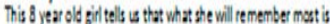
Bess and the various thingsite bugtt the class incliding

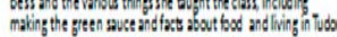

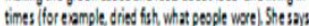
caliet that what she leart was that pu an mave saves out of herbs and soces' He overal memrent abuther enjoyment

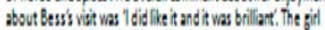

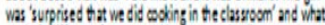
mate it efferent tom nomal leswe vas vall, ve uad

different thing than in normal coling at ahoo and home. In

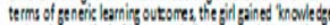
and undercanding of how people lived, ate and dieses in the

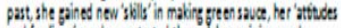

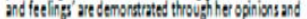

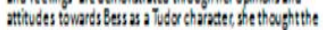
sesion vas bolliant and wassuppied to lean that hebs an spices can be wed in coking and that cooking wud be dorr in

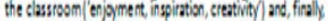
ber comments abut how thing can be done dithenth/ segersts the G.O of 'rtinty betwisuc progession.

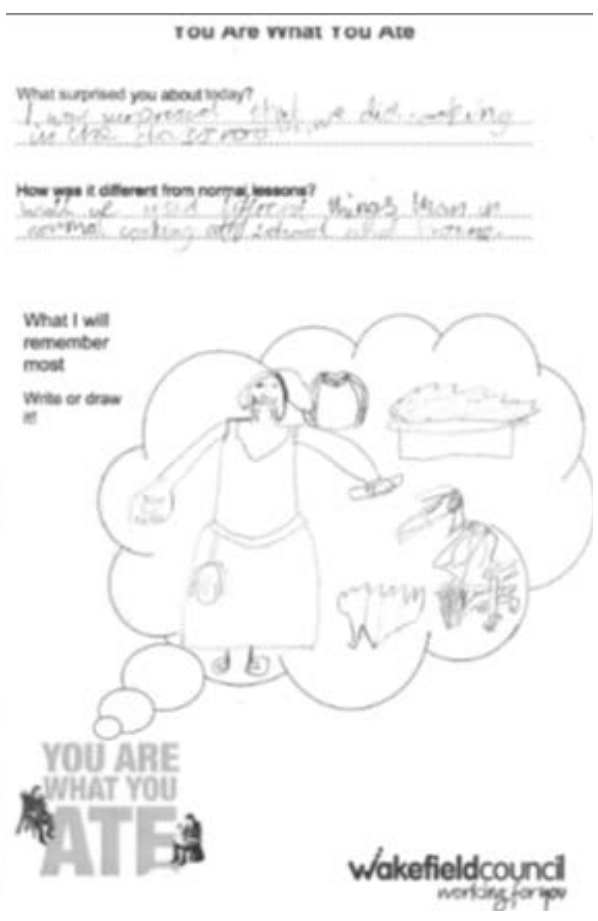

Illustration 4. An example of picture analysis done by Fiona Blair using GLOs (questionnaire From a school Visited in 2013). Picture P Rovided BY THE AUTHORS.

\section{Reach and Significance}

"It was interesting to hear [the children's] answers which reflected their attitudes to food, and the shift from certain opinions once they had heard the facts or new ideas. [...] I learnt a lot too!"52

In this final part of the essay we will share some of the findings of our evaluation, and some thoughts on what we think You Are What You Ate achieved. The full range and richness of the project cannot be captured in a single report and much of it is awaiting deeper investigation. Each type of event deserves individual analysis so only a few comments can be provided here. First of all, it is important to consider the 'reach' of the project: how many people did we encounter over the course of four years. We reported to the Wellcome Trust a total of 147,073 engagements (see Table 1), but it is important to explain how we came by this number and what it represents. We recorded a high

52. A teacher's feedback on a questionnaire after a school workshop on September 14, 2011. 
number of individual engagements at different events, but some of these involved the same people coming to multiple activities. The numbers at each event were collected in different ways. Sometimes there was a head count (school workshops, evening talks). on other occasions we required prior registration (osteology workshops, public conferences). For exhibitions we relied mainly on electronic door entry data used by the museums. In all such cases our exhibition was directly visible in the entrance or main public area.

Table 1. Overall engagement numbers

\begin{tabular}{|c|c|c|}
\hline Participants & $\begin{array}{l}\text { Numbers } \\
\text { engaged }\end{array}$ & Comments \\
\hline $\begin{array}{l}\text { Children aged } 11 \text { and under } \\
\text { in school-based activities }\end{array}$ & 6,929 & $\begin{array}{l}\text { Activities took place in school, in } \\
\text { museum or on Bradford campus }\end{array}$ \\
\hline $\begin{array}{l}\text { Children aged } 11 \text { and under } \\
\text { in family-based activities }\end{array}$ & 677 & $\begin{array}{l}\text { Activities usually in school holidays } \\
\text { in Wakefield's museums and castles }\end{array}$ \\
\hline $\begin{array}{l}\text { Children/young } \\
\text { people at stalls }\end{array}$ & 2,774 & Ages estimated at 18 events \\
\hline Young people aged $12-18$ & 1,084 & Activities mostly in schools \\
\hline Young people in youth clubs & 593 & $\begin{array}{l}\text { Mainly aged } 12-18 \text { but Included } \\
\text { some children under } 11 \text { and some } \\
\text { young people aged } 18-25\end{array}$ \\
\hline Adults & 10,947 & $\begin{array}{l}\text { Engaged with at talks, } \\
\text { conferences and stalls }\end{array}$ \\
\hline Teachers & 641 & $\begin{array}{l}\text { In school or accompanying } \\
\text { children elsewhere }\end{array}$ \\
\hline Youth workers & 121 & Also included some carers \\
\hline $\begin{array}{l}\text { Museum exhibitions } \\
\text { Sugar o Spice } \\
\text { Dark Side of Eating } \\
\text { Food for all Seasons }\end{array}$ & $\begin{array}{l}12,335 \\
28,760 \\
24,398\end{array}$ & $\begin{array}{l}\text { Wakefield Museum } 2011 \\
\text { Pontefract Museum } 2012 \\
\text { Wakefield Museum } 2013\end{array}$ \\
\hline $\begin{array}{l}\text { Mobile exhibition in libraries } \\
\text { Airedale Library } \\
\text { South Elmsall Library } \\
\text { Featherstone Library } \\
\text { Hemsworth Library }\end{array}$ & $\begin{array}{l}18,074 \\
11,478 \\
7,643 \\
20,619\end{array}$ & $\begin{array}{l}\text { October } 2013 \text { to January } 2014 \\
\text { January } 2014 \text { to April } 2014 \\
\text { April } 2014 \text { to July } 2014 \\
\text { July } 2014 \text { to October } 2014^{53}\end{array}$ \\
\hline Total & 147,073 & \\
\hline
\end{tabular}

53. The exhibition then went to the busy Pontefract Library until May 2015, during which period there were more than 80, 000 library users; but this figure was not included in the final report. 
For festival stalls we developed our own robust methods of counting engagement, having discovered quite early on that it was difficult to estimate numbers at events like the Liquorice Festival in Pontefract where there could be as many as forty thousand visitors. ${ }^{54}$ We decided to count as engagements only those who stopped to talk to us or attentively watched us for a while. Also for the sake of consistency we usually ensured that the same person did the counting most of the time. When events were very busy we decided to count at fifteen-minute intervals only. As the examples in Table 2 and Table 3 show, we recorded the hour of the day and the perceived gender and adult/child status of each person. Anecdotally, we were able to notice the aforementioned lack of teenagers. We also observed a marked gender imbalance amongst both adults and children (see Graph 1). Men and boys were consistently much less likely to engage than women and girls. We had a category of person whom we called 'floating dads' -fathers present in the background who declined to participate. We also learned anecdotally that many participants were grandmothers responsible for amusing grandchildren during holidays and at weekends.

Unfortunately, it was not possible to make these kinds of observations at our largest events, the exhibitions, where we had to rely on pre-existing systems of counting that did not gather age and gender data. Exhibitions are much harder to evaluate effectively because they cannot be monitored constantly and most visitors choose not to write comments or fill in questionnaires. We could be more precise at children's workshops, but here we did not note much of a gender imbalance; all children participated equally, especially when they were school-organized activities (not self- or family-selecting). One teacher commented on how well the osteology workshop engaged 'both' boys and girls. ${ }^{55}$ This observation was also made repeatedly by the Bradford team, especially Alan Ogden.

Table 2. Engagement numbers for Castleford Market, December 15, $2012^{56}$

\begin{tabular}{|l|l|l|l|l|l|}
\hline \multicolumn{1}{|c|}{ Time } & Women & \multicolumn{1}{|c|}{ Men } & \multicolumn{1}{|c|}{ Boys } & \multicolumn{1}{|c|}{ Girls } & \multicolumn{1}{c|}{ Total } \\
\hline $10.00-11.00$ & 20 & 18 & 4 & 12 & 54 \\
\hline $11.00-12.00$ & 25 & 19 & 6 & 8 & 58 \\
\hline $12.00-13.00$ & 20 & 19 & 9 & 13 & 61 \\
\hline $13.00-14.00$ & 15 & 6 & 2 & 3 & 26 \\
\hline
\end{tabular}

54. Due to the lack of a system at the start, stall attendance between July 2010 and February 2011 was not included in the final total of engagements.

55. Buckberry, Jo; Ogden, Alan; Shearman, Vicky; Mcleery, Iona. "You Are What You Ate...": 109.

56. This was a stall at a weekly high-street market in a small former mining town. We were the only noncommercial activity present. The weather was foggy and cold; it was dark before we finished. 


\begin{tabular}{|l|l|l|l|l|l|}
\hline $14.00-15.00$ & 20 & 13 & 6 & 10 & 49 \\
\hline $15.00-16.00$ & 12 & 15 & 1 & 8 & 36 \\
\hline Total & $\mathbf{1 1 2}$ & $\mathbf{9 0}$ & $\mathbf{2 8}$ & $\mathbf{5 4}$ & $\mathbf{2 8 4}$ \\
\hline
\end{tabular}

Table 3. Engagement numbers for Pontefract Liquorice Festival, July 14, $2013^{57}$

\begin{tabular}{|l|l|l|l|l|l|}
\hline \multicolumn{1}{|c|}{ Time } & Women & \multicolumn{1}{c|}{ Men } & \multicolumn{1}{c|}{ Boys } & \multicolumn{1}{c|}{ Girls } & \multicolumn{1}{c|}{ Total } \\
\hline $10.00-11.00$ & 179 & 124 & 52 & 65 & 420 \\
\hline $11.00-12.00$ & 246 & 139 & 50 & 80 & 515 \\
\hline $12.00-13.00$ & 131 & 78 & 34 & 64 & 307 \\
\hline $13.00-14.00$ & 102 & 58 & 29 & 51 & 240 \\
\hline $14.00-15.00$ & 78 & 45 & 33 & 50 & 206 \\
\hline $15.00-16.00$ & 84 & 41 & 20 & 19 & 164 \\
\hline Total & $\mathbf{8 2 0}$ & $\mathbf{4 8 5}$ & $\mathbf{2 1 8}$ & $\mathbf{3 2 9}$ & $\mathbf{1 8 5 2}$ \\
\hline
\end{tabular}

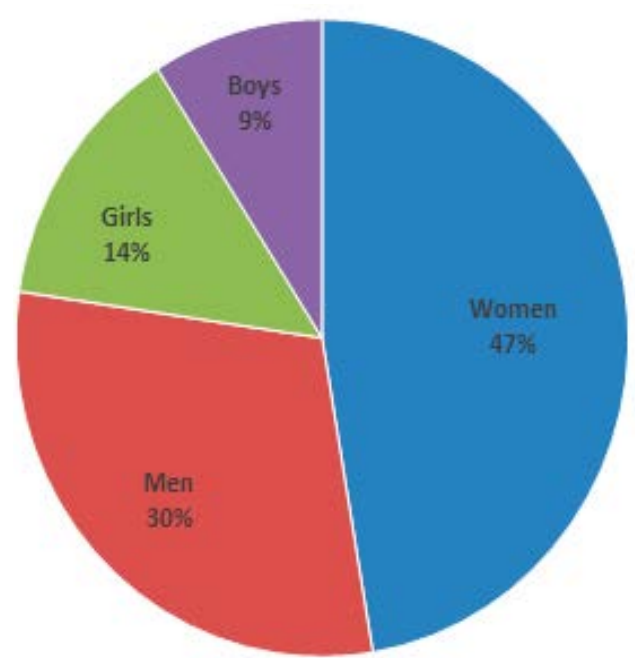

Graph 1. Percentage break down of Stall ENGAGEMENT, JUNE 2011-JuLy $2014(\mathrm{~N}=12,237)$

57. This was a stall at a very large festival on the high street. There was a great variety of family-oriented activities available, both free and commercial. The weather was warm and sunny. 
Some of the children's responses to specific questions about the in-school workshop they attended did indicate gender differences, Although over $80 \%$ of the children said they learned new things that surprised them about food and eating and agreed that they had been given new ideas about how to eat more healthily, only $70 \%$ wanted to cook more at home. However, girls were significantly more likely than boys to want to cook at home and find out more about food (see Graph 2). Younger children aged 7-8 were also more willing to cook than the 9-11 year olds. As our dataset consists of 3906 responses, it is a robust method of corroborating the findings of nutritional epidemiologists that on average boys eat fewer fruits and vegetables a day than girls, and that it is important to engage children as early as possible in healthy eating. ${ }^{58}$ The nature of the project as a public engagement exercise rather than a research project meant that we were not able to explore and explain these gender differences any further.

The effect of gender on KS2 pupils' response to the Medieval/Tudor food session

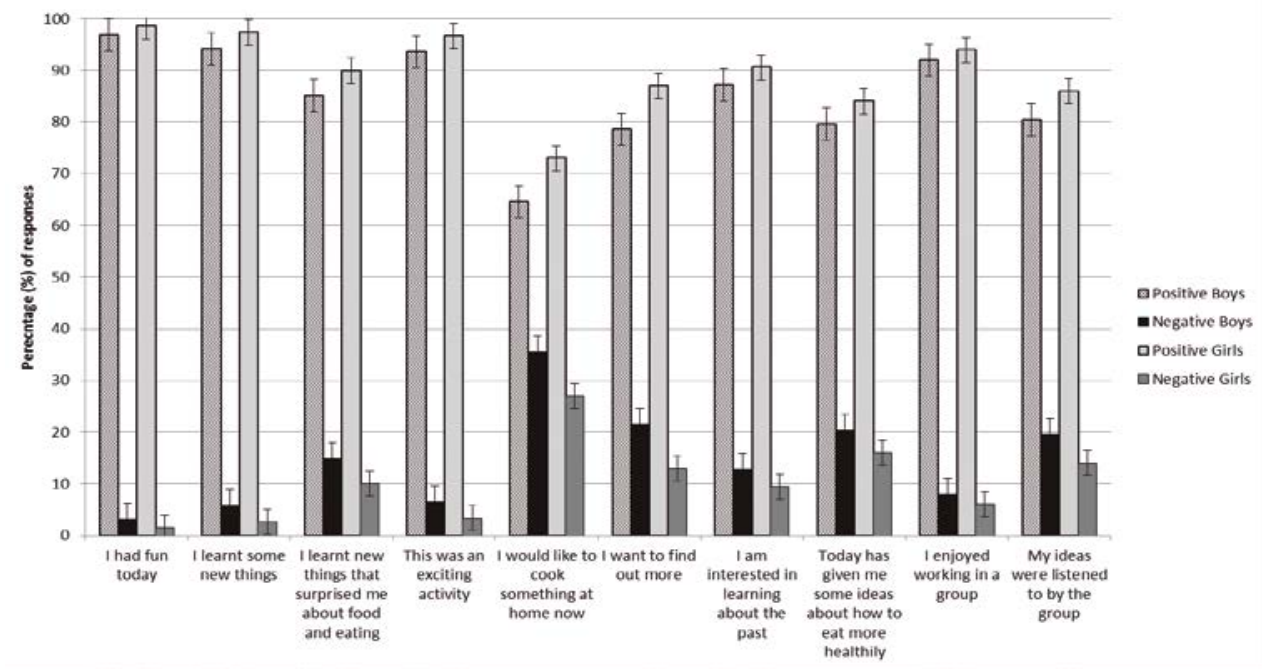

Graph 2. Analysis of Children's questionnaires from in-school workshops at Key Stage 2 (N=3909)

58. Christian, Meaghan; Evans, Charlotte; Nykjaer, Camilla; Hancock, Neil; Cade, Janet. "Evaluation of the Impact of a School Gardening Intervention on Children's Fruit and Vegetable Intake: a Randomised Controlled Trial". International Journal of Behavioral Nutrition and Physical Activity, $11 / 99$ (2014): <http:// dx.doi.org/10.1186/s12966-014-0099-7> (10 June 2016). 
Numbers in themselves are not necessarily meaningful, as it is the depth of engagement that is important. We regard the youth-work carried out by Jane Howroyd in small sessions totalling 593 young people and 121 youth workers to be as valuable, if not more so, as the 65, 493 visits to our exhibitions. ${ }^{59}$ Helping one young person at a youth club to learn that butter comes from a cow having just made her own butter was a major achievement in its own right. This point therefore brings us onto the 'significance' of our project, both in terms of the individual activities and in terms of the project as a whole, something that is much more complex to evaluate.

Our main method of evaluating individual activities is through analysis of the hundreds of questionnaires that we collected. Due to the limitations of space, only the eighteen festival stalls will be explored here in detail, although a substantial amount of feedback on our other activities has already been provided. The aim of the stall was two-fold: to promote exhibitions and other events, and to provide an opportunity for food tastings and food displays within communities. We tried to create a good 'flow' between the food tastings, the food displays, the information that we handed out, and a children's activity: pounding spices to make a pomander (see illustration 6), often using some of the same ingredients in the tastings. ${ }^{60}$ We were keen to encourage fruit/vegetable identification and tastings since the research of food scientists and nutritional epidemiologists has suggested that familiarity with a wider range of tastes and foodstuffs is likely to lead to a more diverse and healthier diet. ${ }^{61}$ We observed that children whose parents/ carers would not try something were much less likely themselves to eat what was offered to them. Out of 335 children's questionnaires, only 128 (38\%) stated that they tried the foods. We also wanted to communicate some recent research on medieval (and early-modern) diet and eating behaviours and their relationship to health. Our questions therefore invited some more general statements about health and food in the past in keeping with the emphasis on social status and seasonality in our displays and recipes.

59. We were delighted to be able to continue an aspect of these youth clubs via a leaders' training weekend in Wakefield for the Young Archaeologists' Club in April 2016. See: Young Archaeologists' Club. "YAC Leaders'weekend.. what we did in Wakefield". Young Archaeologists' Club. 10 June 2016 $<$ http://www.yac-uk.org/news/yac-leaders-weekend-what-we-did-in-wakefield>.

60. Caroline Yeldham and Iona $\mathrm{M}^{\mathrm{c}}$ Cleery mainly adapted recipes from: Hieatt, Constance; Hosington, Brenda; Butler, Sharon, eds. Pleyn Delit: Medieval Cooking for Modern Cooks. Toronto: Toronto University Press, 1996.

61. Remington, Anna; Añez, Elizabeth; Croker, Helen; Wardle, Jane; Cooke, Lucy. “Increasing Food Acceptance in the Home Setting: a Randomized Controlled Trial of Parent-administered Taste Exposure with Incentives". American Journal of Clinical Nutrition, 95/1 (2012): 72-77; Wardle, Jane; Herrera, Maria; Cooke, Lucy; Gibson, E. Leigh. "Modifying Children's Food Preferences: the Effects of Exposure and Reward on Acceptance of an Unfamiliar Vegetable". European Journal of Clinical Nutrition, 57/2 (2003): 341-348. 


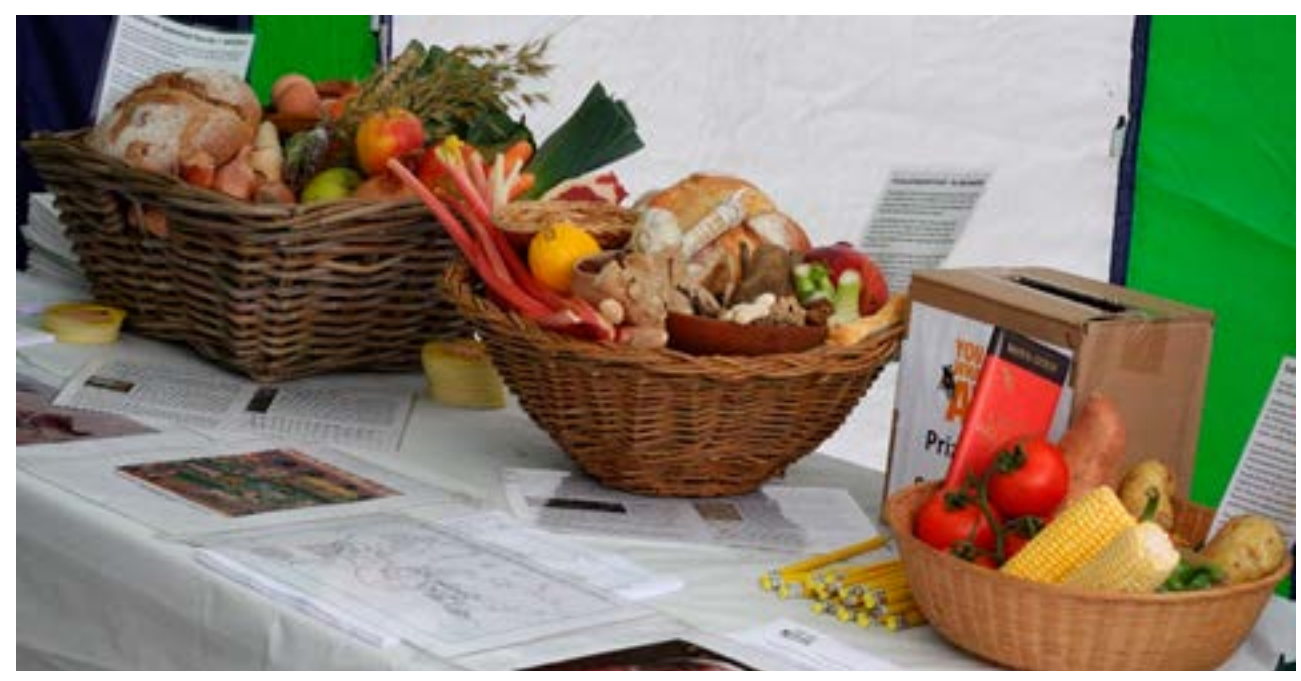

Illustration 5. You Are What You Ate display at the launch of Wakefield Museum in March 2013. Picture by Fiona Blair.

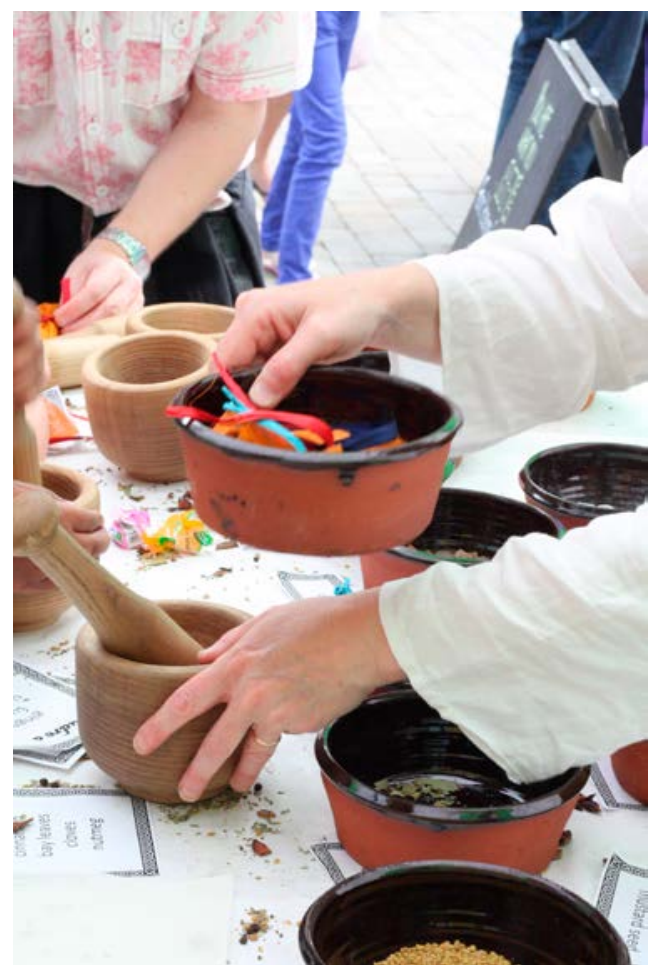

IlLustration 6. ChildRen POUNDing SPICES, Pontefract Liquorice Festival, July 2013. Picture by Fiona Blair.

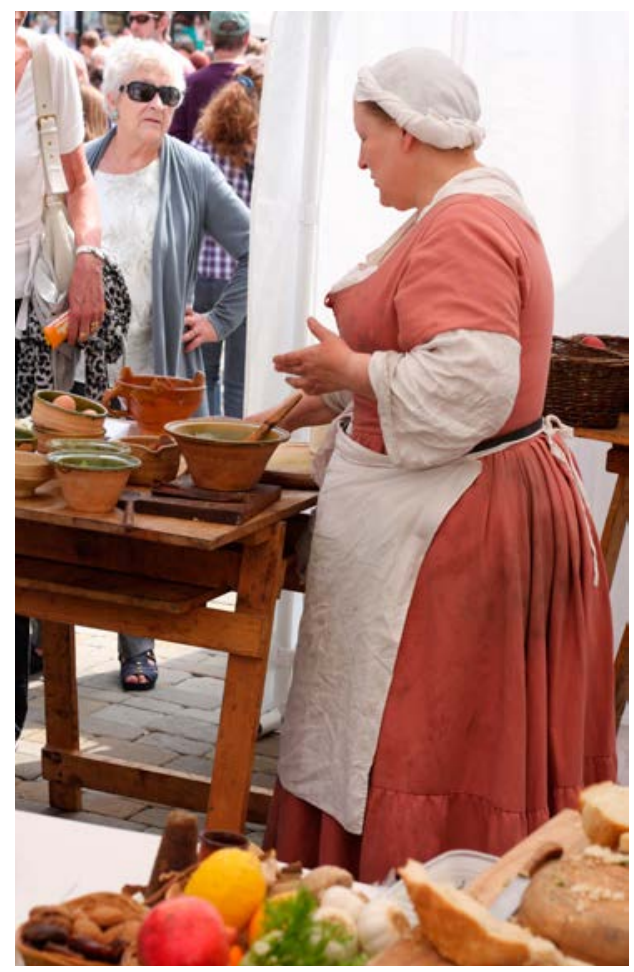

Illustration 7. Pontefract Liquorice Festival 2011. Picture by Fiona Blair. 
As can be seen in illustration 5, our stall included food baskets that displayed "food for the poor" (seasonal fruits and vegetables — sometimes dried- mixed grain bread, oats, eggs and some plastic bacon), "foods for the rich" (including white bread, red meat —as represented by plastic meat and toy animals - sugar and spices) and "New World foods". This last category included potatoes as well as many of the brightly-coloured, tasty foods that children enjoy today (sweetcorn, tomato, peppers), triggering some interesting conversations about what it was like to live without chips and chocolate. ${ }^{62}$ Further analysis could establish whether there is any correlation between the comments, the time of year (were strawberries, fresh herbs and peas on display or was it a case of onions, dried apples and nuts?), and whether project cook Caroline Yeldham was cooking at the time (this was the case at most events between 2010 and 2013 as in illustration 7).

The design of our questionnaires evolved over time as we became more practised in developing questions. We tried to capture the extent of pre-awareness of our project and its other activities, prior knowledge of the subject and immediate reactions to what we were doing. The nature of the activity means that the engagement was short-term and anonymous, without much opportunity for follow-up, but we tried to capture immediate 'reflection' on diet and nutrition over time. It was only very rarely at stalls that we got anecdotal evidence of how the schools workshops had been represented at home by children. One set of parents at an event in Castleford was amazed to taste the green sauce that their child had talked about at length but not very coherently! We did have numerous repeat visits from people who deliberately sought us out at festivals, although this was not well-captured in the questionnaires as people rarely filled them in twice. Comments sent to us later are very valuable such as the following:

this is an historical resource that is interactive, and so seems so much more accessible than museum display. I think that's what I find most inspiring about the whole thing, so getting to sample a few dishes, and discuss with yourself the various ingredients available and habits of the times was thoroughly interesting. ${ }^{63}$

Reflection on an interactive outdoor activity can vary a great deal. Altogether $83 \%$ of adults felt that they learned something new at the stalls, but this percentage varied at individual events depending on whether we were at a food-related festival and speaking to chefs and dedicated 'foodies' or at an ordinary market. We felt that we made more of an impact on the ordinary high street or in a regular market

62. Useful introductions in English include: Adamson, Melitta Weiss. Food in Medieval Times. Westport: Greenwood Press, 2004; Arn, Mary-Jo, ed. Medieval Food and Drink. Binghamton: Center for Medieval and Renaissance Studies, 1995; Carlin, Martha; Rosenthal, Joel, eds. Food and Eating in Medieval Europe. London: The Hambledon Press, 1998; Brears, Peter. Cooking and Dining in Medieval England. Totnes: Prospect Books, 2008; Woolgar, Christopher. The Culture of Food in England, 1200-1500. New Haven: Yale University Press, 2016; Montanari, Massimo. Medieval Tastes: Food, Cooking and the Table, ed. and trans. Beth Archer Brombert. New York: Columbia University Press, 2015.

63. E-mail correspondence, June 20, 2013. 
because of the socially and culturally more diverse audience that we observed and the greater likelihood that what we were doing was less familiar. However, because we deliberately did not gather data on socio-economic background or ethnicity it is difficult to prove this. In contrast we do know that apples and carrots were the most mentioned favourite fruits and vegetables of 335 children. We also know that only $15 \%$ of 163 adults think that rickets (Vitamin D deficiency) is still a health problem in Britain today. ${ }^{64}$ Perhaps surprisingly, some of the same people $(63 \%$ of 158 polled adults) thought that medieval people were healthier than us. The reasons most commonly given were that medieval food was less processed or contained less sugar or fat (51 responses), or that it was home-grown, more 'natural' food ( 15 responses). A few people commented that health depended on social status and the season of the year; those who did not think that medieval people were healthier worried about lack of freshness and low protein levels for the poor. These comments show reflection on both modern and medieval diet as a direct consequence of the contrasts that we set up in our displays. Also a sign of reflective learning are comments such as the following in response to the question "did you learn something new?":

- "I didn't know sweetcorn, tomatoes and peppers weren't from England" (adult);

- "Had no idea tomatoes were American or that gingerbread was savoury" (adult);

- "The differences between rich and poor diets" (adult);

- "Potatoes weren't in England in the Middle Ages" (child);

- "Spices used to be very expensive. Spices come from a long way away" (child). ${ }^{65}$

Even comments that sound slightly odd, such as: "Most vegetables come from America", can be interpreted as reflection on that child's own diet, which probably contains a lot of sweetcorn, tomatoes and potatoes. ${ }^{66}$ Some adults were very pleased that the project engaged with children's tastes in such an educational way. One of them commented that it was "going back to basics about food - educating youngsters- just what is needed in this age of fast foods"; others said, "showing my daughter different types of food was educational for her", and "It's great for kids. Very hands on. Good ideas on nutrition without preaching". ${ }^{67}$ This last point was certainly pleasing to hear, as we had hoped to be able to present a message about food past and present that was not 'preachy'.

\footnotetext{
64. This question was linked to our Dark Side of Eating exhibition in 2012 in order to encourage festival goers to visit Pontefract museum and learn more about rickets past and present: $\mathrm{M}^{\mathrm{c}}$ Cleery, Iona; Buckberry, Jo. "Research News: Rickets on the Increase?". You are what you ate. 21 July 2016 $<$ http://www.leeds.ac.uk/youarewhatyouate/news/news-rickets.html>; Pearce, Simon; Cheetham, Tim. "Diagnosis and Management of Vitamin D deficiency". British Medical Journal, 340 (2010): <http://dx.doi. org/10.1136/bmj.b5664> (21 July 2016).

65. Comments collected at the Pontefract Liquorice Festival on July 10, 2011 and July 14, 2013; Manor Lodge Sheffield on June 19, 2011; Eureka! Children's Museum, Halifax on August 19, 2012.

66. Comment collected at Eureka! Children's Museum in Halifax on August 19, 2012.

67. Comments collected on May 18, 2013 at Leeds Kirkgate Market and on February 22, 2014 at the Food, Drink and Rhubarb festival in Wakefield.
} 


\section{Conclusion}

"It caught the imagination of participating children and young people in a novel way, [...] learning from this would lead to the development of future interventions in this area [of childhood obesity], which remains one of key strategic importance for the public health service". ${ }^{68}$

In 2011 the Director of Public Health for Wakefield Council, Dr Andrew Furber, visited our Sugar and Spice exhibition at Wakefield Museum and commented favourably on its potential for tackling childhood obesity. He also twice came to see Food for all Seasons in summer 2013, bringing with him Dr Kevin Fenton, Director of Health and Well-being at Public Health England. Fenton later wrote in response to the exhibition:

“...history can help uncover our country's rich food heritage and may provide a sense of context for the current challenges of unhealthy habits we now see.....an exhibition on how we got to where we are today and the continued evolution of our food and tastes would be interesting!"69

This comment suggests not only would further historical exhibitions be welcomed by a health professional, but that it is the content of the exhibition or activity that informs the health agenda. Much of the recent research on the health benefits of visiting museums focuses on the role of group participation, community cohesion, the mental stimulation of handling objects, and the use of relaxing space, colour and design. ${ }^{70}$ These are all very important components of physical and mental well-being, but few studies comment on the intellectual or narrative content of the museum displays as beneficial in themselves to health.

The You Are What You Ate project was a rare example of a collaboration that contributed to community well-being through both its wide range of activities appealing to all ages and through its archaeological, nutritional and historical content. We found that most of the people we engaged with, including young children, were aware of public health messages about how to improve nutritional health; for example, eating at least five fruits and vegetables a day. What was different about this project was our way of making these messages meaningful and engaging. ${ }^{71}$ We grounded them in children's own classroom practices and shopping trips, making them think about their own teeth and skeletons, and getting them to think about the foods they themselves consume. A favourite piece of feedback from the osteology workshops in Bradford was a child who wrote: "If you don't

68. Furber, A., telephone interview, September 5, 2012.

69. Fenton, K., e-mail correspondence, June 20, 2013.

70. Chatterjee, Helen; Noble, Guy. Museums, Health and Well-being...; Bodley, Alison. History to Health...

71. See: Bodley, Alison. History to Health...: 8; where she contrasts our project favourably to a well-known health campaign: "[it] does get people looking at the issues and perhaps in a more engaging way". 
eat your greens you will get holes in your brain". ${ }^{72}$ This was an eleven-year old's understanding of cribra orbitalia, linked by the Bradford research team to both Vitamin $\mathrm{C}$ and iron deficiencies in our sessions. ${ }^{73}$ Children and adults who participated in the project had the opportunity to learn why not all people have had access to the same foods as us all year round. They also got a chance to try new foods for themselves and reflect on where they come from and why. Research into the history of medieval food has long taken place outside of the academy in museums, libraries, re-enactment groups and Living History centres; what we did was bring bioarchaeology into the mix and combine it with up-to-date nutritional research. We found that it was the combination of bioarchaeological, historical and nutritional research that made this project successful. Any one of these on its own might not have had the same impact.

Our aims in 2010 as stated above were to enable public engagement with multi-disciplinary research, to bring together a wide range of experts in museum education, bioarchaeology, history and nutrition in order to deliver innovative activities that encouraged public participation in cultural activities. We aimed to bring dietary issues to a wide audience in Yorkshire, working with schools, going out onto the street at festivals and putting on exhibitions in order to encourage public debate and personal reflection about eating habits through exploration of the dietary choices of the past. We also wanted to share and disseminate our methods and experiences in order to inspire further public engagement initiatives. We feel that we have managed to achieve all of these things, forging friendships and creating potential for further research-related activities. The museum professionals were able to access substantial resources and research for a wide variety of new ventures that facilitated engagement, especially with young people, in regions and contexts that are usually hard to reach. The project had the crucial effect of raising the profile of the museum service within Wakefield Council during a period of recession, thereby helping to safeguard cultural activities for the future. The university-based academics and their students learned how to put on exhibitions and workshops, and communicate more effectively with a wide cross-section of society. We learned that public engagement can be both fun and rewarding. Not being able to avoid a final food-related metaphor: this project fed back into research in so many ways, and ultimately provided so much food for thought that it will continue to have a legacy for a long time to come.

72. Comment collected on June 22, 2012.

73. Cribra orbitalia are holes in the bone that forms the roof of the eye sockets. The exact cause is debated, but hypotheses include anaemia (including iron deficiency), scurvy and possible rickets, as well as infection and non-specific physiological stress. 